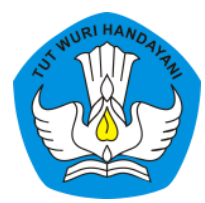

Page: 707-722

\title{
Pengembangan Garis Ajaib untuk Meningkatkan Prestasi Belajar Bilangan Bulat Siswa Sekolah Dasar
}

\author{
Tanti Ratna Wulandari \\ Sekolah Dasar Negeri Wates Kabupaten Kediri \\ Contributor Email: ikmalazza@gmail.com
}

Article Url: http:/ / ojsdikdas.kemdikbud.go.id/index.php/didaktika/article/view/151

\begin{abstract}
Mathematics grade VI achievement in Wates SDN integer material is still disappointing. This is indicated by the low student achievement. The results of problem identification are the factors of the media's lack of interest in learning. For this reason, the writer makes a media that is expected to help understanding in learning. The media are named magic lines. The purpose of the report is to provide an overview of the process of making, the learning process, and student achievement after the development of the magic line. In the process of creating this magic line media the authors develop it with the concept of $R \mathcal{E} D$, namely research and development. During the learning process students look active and enthusiastic. This shows that learning with magic line media can increase student involvement in learning. The results of data analysts showed a significant improvement in the aspects of knowledge and skills. KKM aspects of knowledge and skills have increased to $80 \%$ from $60 \%$. The mean knowledge of 65.2 rose to 78.2 . The aspect of average skill before 67.6 rose to 80.8 . Thus it can be concluded that the magic line media is able to increase student learning achievement.
\end{abstract}

Keywords: Development, Magic Lines, Learning Achievement, Integers 


\begin{abstract}
Abstrak
Prestasi belajar matematika kelas VI SD belum memuaskan. Hal ini diindikasi karena proses pembelajaran yang belum menarik dan anak cepat bosan. Hasil identifikasi masalah adalah faktor kurang menariknya media dalam pembelajaran. Untuk itu penulis melakukan penelitian dan pengembangan (RED) agar dapat membantu pemahaman dalam pembelajaran. Penelitian dan pengembangan menghasilkan sebuah media pembelajaran yang disebut Garis Ajaib. Dalam proses implementasi, pembelajaran di kelas, siswa terlihat aktif dan antusias. Hal ini menunjukkan pembelajaran dengan media Garis Ajaib mampu meningkatkan keterlibatan siswa dalam belajar. Hasil analis data menunjukkan peningkatan yang signifikan dari aspek pengetahuan dan keterampilan. KKM aspek pengetahuan dan keterampilan mengalami peningkatan hingga 80\% dari 60\%. Rerata pengetahuan 65,2 naik menjadi 78,2. Aspek keterampilan rerata sebelumnya 67,6 naik menjadi 80,8 Dengan demikian dapat disimpulkan bahwa media Garis Ajaib mampu meningkatkan prestasi belajar siswa.
\end{abstract}

Kata Kunci: Pengembangan, Garis Ajaib, Prestasi Belajar, Bilangan Bulat

\title{
A. Pendahuluan
}

Pendidikan di negaIndonesia mengalami perubahan dan perbaikan di berbagai sistem. Pergantian kurikulum dari masa ke masa adalah wujud tanggapan pemerintah pada tantangan dan tuntutan di masyarakat yang berkembang. Karena memang di dunia ini tidak ada yang abadi kecuali perubahan itu sendiri. Guru sebagai ujung tombak pembangunan di bidang pendidikan haruslah memiliki profesionalitas dalam mengembangkan tugasnya. Guru yang mempunyai profesionalitas di dalam kinerjanya akan menumbuhkan suasana pembelajaran yang menarik dan menyenangkan sehingga menumbuhkan situasi kondusif bagi peserta untuk meningkatkan prestasinya.

Wilandari (2019:64) berkata bahwa kemajuan suatu bangsa akan ditentukan oleh karakter warga negaranya, kompetensi intelegensi masyarakat, keunggulan berpikir warga, sinergi para pemimpinnya dan lain lain. Sehingga dapat diambil kesimpulan bahwa pendidikan karakter sangatlah penting dalam pembangunan moral dan kepribadian bangsa. 
Sejalan dengan pendapat di atas media pembelajaran diharapkan dapat membangun karakter kritis anak dan meningkatkan kualitas pembelajaran.

Menurut Isjoni (2016:11) Pembelajaran merupakan sesuatu yang dilakukan oleh peserta didik, bukan diciptakan untuk siswa. Pembelajaran pada hakikatnya adalah usaha pendidik untuk membantu peserta didik melaksanakan kegiatan belajar. Tujuan pembelajaran yakni terwujudnya efisiensi dan efektivitas aktivitas belajar yang dilakukan peserta didik. Pihak-pihak yang terlibat dalam pembelajaran adalah pendidik (perorangan dan/atau kelompok) serta peserta didik (perorangan, kelompok, dan/atau komunitas) yang berinteraksi edukatif antara satu dengan lainnya. Isi kegiatan yakni bahan (materi) belajar yang bersumber dan kurikulum suatu program edukasi. Proses kegiatan adalah langkah- langkah atau tahapan yang dilalui pendidik dan perserta didik dalam pembelajaran.

Komalasari (2015:3) memaparkan bahwa pembelajaran dapat dimaknai sebagai suatu keutuhan sistem atau proses yang membelajaran pelaku didik/pembelajar yang dirancang, diterapkan dan dinilai dengan sistematis agar siswa tersebut bisa mencapai tujuan-tujuan pembelajaran yang efektif dan efisien. Senada dengan pendapat di atas penulis meyakini jika guru sebagai fasilitator menciptakan suasana belajar yang kondusif bagi peserta didiknya, maka tujuan pembelajaran akan mudah tercapai.

Setiap aktifitas akademik termasuk pembuatan karya inovasi pembelajaran akan memberikan manfaat bagi subyek-subyek didik di sekitarnya atau dalam arti lingkungannya. Dengan adanya inovasi pembelajaran akan berdampak bagi: (1) siswa akan meningkat motivasi belajarnya. (2) siswa akan meningkatkan prestasi belajarnya. (3) Bagi Guru, bisa digunakan untuk instrument pemecahan masalah dalam pembelajaran. (3) Bagi Kepala sekolah, karya inovasi pembelajaran akan mendongkrak prestasi peserta didik yang dapat menaikkan mutu lembaga pendidikan yang dipimpinnya. (4) Bagi semua pihak, bisa dijadikan referensi untuk melakukan penelitian yang baru. 
Saat ini, pembelajaran matematika terutama pada materi bilangan bulat kelas VI SDN Wates Kecamatan Wates Kabupaten Kediri masih belum begitu maksimal. Hal ini ditandai dengan rendahnya hasil belajar peserta didik pada materi tersebut. Hal ini dapt dilihat dari dua indikasi yakni rendahnya nilai rata-rata kelas dan rendahnya presentase ketuntasan klasikal. Nilai rerata kelas masih berkutat di angka 5,6 sedangkan persentase ketuntasan belajar masih 50\%. Berbagai masalah tersebut, perlu dicaraikan pemecahannya agar siswa menyenangi pelajaran matematika dan proses pembelajaran berikutnya menjadi lebih baik.

Dari latar belakang tersebut, dapat diidentifikasi masalah sebagai berikut (1) bagaimana proses pembuatan media agar dapat meningkatkan motivasi belajar matematika siswa SD? (2) Bagaimana proses pengembangan media pembelajaran matematika untuk mata pelajaran matematika di Kelas VI SDN?

Dari berbagai maslaah tersebut, maka dapat dirumuskan tujuan dari peneltian ini yaitu: 1) menemukan media pembelajaran yang dapat dimanfaatkan untuk pembelajaran matematika, khususnya materi bilangan pada kelas VI SD?; 2) bagaimana model media pembelajaran yang menarik untuk materi bilangan bilangan pada kelas VI SD?;3) untuk mengetahui bagaimana respon siswa terhadap media pembelajaran materi bilangan pada kelas VI SD?

\section{B. Metode}

Pada penelitian dan pengembangan ini peneliti menggunakan pendekatan R \& D yakni (research and development). Sebagaimana diungkapkan oleh Sugiyono (2009:407) metode R \& D adalah metode penelitian yang diterapkan dalam pembuatan suatu produk tertentu untuk memberikan pengujian pada efektifitasnya. Produk ini tidak selalu berwujud dalam perangkat keras seperti buku, alat tulis dan sebagainya tetapi juga bisa berwujud perangkat lunak.

Bertolak dari pendapat ini Peneliti mencoba merancang dan mengembangkan media pembelajaran matematika pada materi bilangan bilangan pada kelas VI SD. Penelitian ini dilakukan selama 3 bulan dari 
bulan Maret sampai dengan Mei 2018. Subjek penelitian ini adalah siswa kelas VI SDN Wates tahun pelajaran 2018/2019. Populasi penelitian seluruh siswa kelas VI SDN Wates tahun pelajaran 2018/201, sedangkan sampelnya adalah 25 orang siswa kelas VI A. Analisis data yang digunakan yaitu metode analisis data kuantitatif dan kualitatif menggunakan instumen tes untuk memperoleh data kuantitatif dan non tes (Pengamatan dan wawancara mendalam) untuk memperoleh data kualitatif.

Adapun skema dari model penelitian ini adalah:

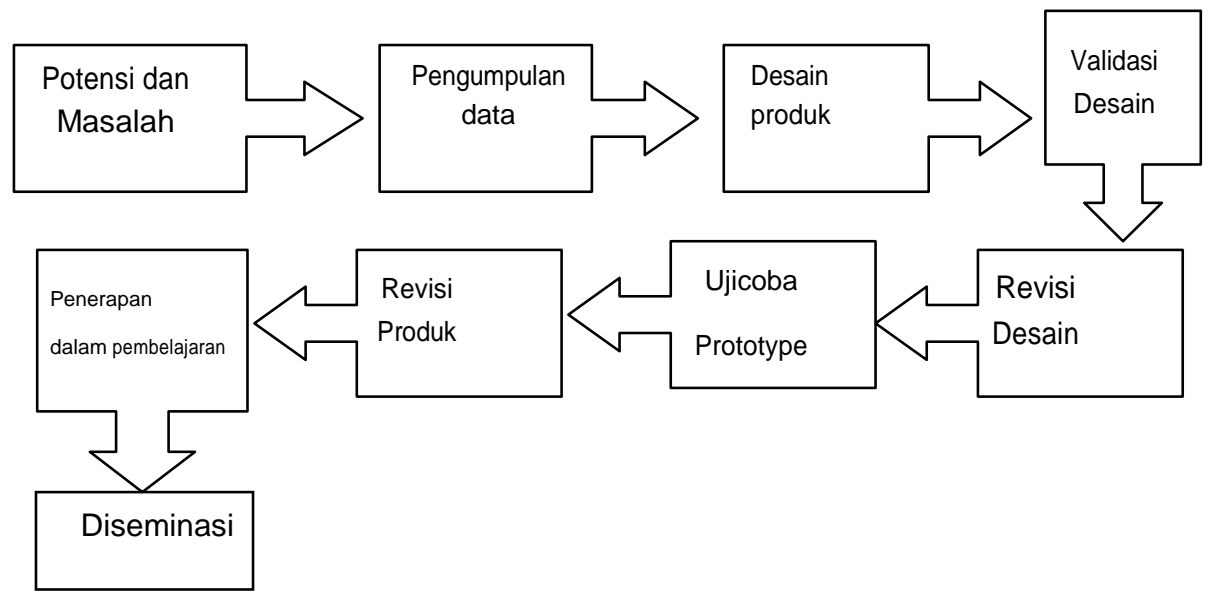

Gambar 1 Bagan Proses Penemuan/ Pembaruan

\section{Hasil dan Pembahasan}

Berawal dari rendahnya prestasi belajar matematika di kelas VI pada materi bilangan bulat, penulis tertantang untuk membuat suatu media yang bisa membuat siswa lebih aktif dalam pembelajaran dan prestasi belajar matematikanya naik. Melihat kondisi tersebut, kemudian penulis melakukan analisis terhadap kurikulum dan melihat buku pelajaran siswa. Hasil dari analisis tersebut, penulis merasa bahwa untuk pembelajaran bilangan agar siswa mudah paham dan tidak bosan diperlukan media pembelajaran yang menarik. Setelah diskusi dengan beberapa guru dan adanya dukungan Kepala Sekolah dan Pengawas, kemudian penulis termotivasi untuk membuat media pembelajaran. adapun langkah-langkah yang penulis lakukan sebagai berikut: 


\section{Melakukan analisis kebutuhan}

Langkah pertama yang penulis lakukan yaitu melakukan pengamatan dan diskusi dengan siswa. Dalam diskusi tersebut, ternyata siswa tampak antusias dalam pembelajaran kalau guru memanfaatkan media. Setelah melakukan beberapa percobaan di rumah, kemudian ditemukan sebuah gambaran bagaimana membuat media pembelajaran matematika yang mudah, murah, tetapi tetap menarik dan efektif untuk pembelajaran khususnya materi bilangan bulat.

\section{Membuat Rancangan Media Pembelajaran}

Setelah analisis kebutuhan, kemudian membuat rancangan media. Media Garis ajaib ini diharapkan dapat membantu siswa dalam pembelajaran materi bilangan bulat. Adapun media garis ajaib ini mempunyai tiga bagian utama yakni:

a. Garis geser

Garis geser ini dibuat dari lembaran triplek lalu ditulis bilangan bulat

b. Papan utama

Papan utama berfungsi sebagai papan acuan

c. Pipa gorden

Pipa gorden berfungsi sebagai penggerak garis geser

\section{Pengembangan Media Pembelajaran}

Setelah rancangan selesai dibuat, kemudian dikembangkan media peembelajaran Garis Ajaib untuk materi bilangan bulat. Karya inovasi pembelajaran ini mampu memahamkan konsep matematika pada bilangan bulat. Verbalisme pada konsep bilangan bulan lebih dapat dikurangi dengan adanya simulasi menggunakan garis ajaib. Fungsi media Garis ajaib adalah untuk menerangkan konsep bilangan bulat pada pelajaran matematika di kelas VI.

Setelah media pembelajaran selesai dikembangkan, kemudian dibuat Petunjuk penggunaan media Garis Ajaib untuk pengajaran Matematika dengan materi Bilangan Bulat. Adapaun petunjuk pemanfaatannya sebagai berikut:

Ketika siswa ingin menjelaskan operasi hitung berapa hasil $-2+3$ ?

Langkah-langkahnya adalah:

a. Siapkan media garis ajaib 
b. Geserlah garis geser sehingga simbol bilangan -2 lurus dengan bilangan 0 pada papan utama sebagai acuan.

Gambar 2 Proses simulasi operasi hitung bilangan bulat contoh 1

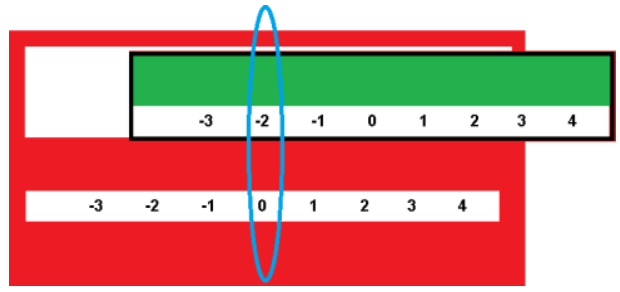

c. Lalu karena soalnya + 3 maka kita gerakkan garis geser kearah kiri sebanyak tiga langkah.

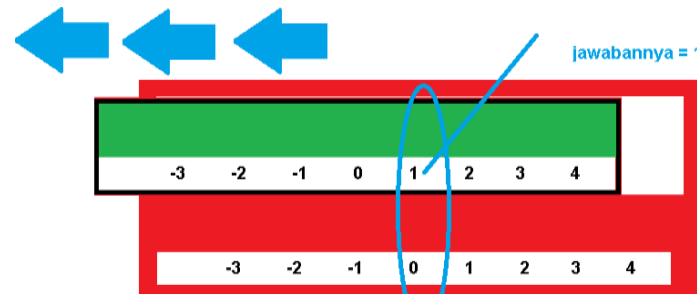

Gambar 3 Lanjutan proses simulasi operasi hitung bilangan bulat contoh 1

d. Sudah nampak bahwa jawaban dari soal $-2+3$ adalah 1

e. Lalu misalkan siswa mengoperasikan soal yang lain

f. Misalkan soalnya $3+(-4)$. Geserlah garis geser sehingga bilangan 3 berhimpitan dengan bilangan 0

Gambar 4 Proses simulasi operasi hitung bilangan bulat contoh 2

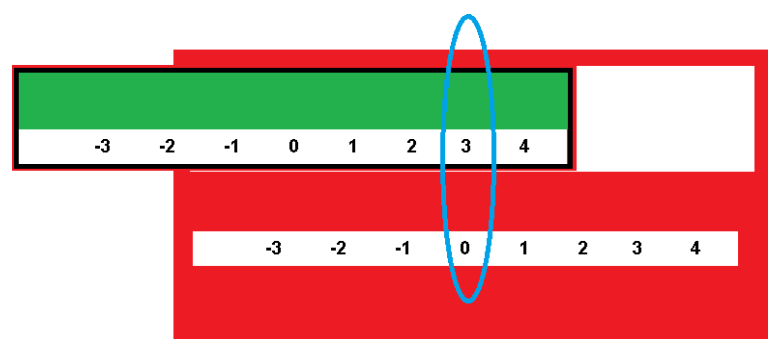

g. Lalu geserlah ke kanan sebanyak 4 langkah kekanan 


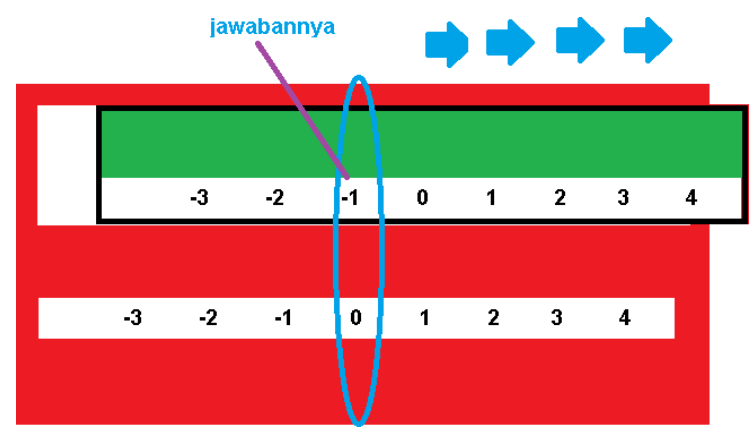

Gambar 5 Lanjutan proses simulasi operasi hitung bilangan bulat contoh 2

h. Maka nampaklah jawabannya adalah-1

Demikian seterusnya pembelajaran dilakukan secara kelompok agar peserta didik juga mendapatkan tutor sebaya selama pengoperasian garis ajaib.

\section{Potensi dan masalah}

Seperti yang dijelaskan di muka bahwa pada tahap ini penulis mengidentifikasi masalah pada pembelajaran sebelumnya. Rendahnya prestasi belajar membuat penulis berinisiasi untuk menciptakan karya inovasi pembelajaran yang disebut dengan garis ajaib.

\section{Pengumpulan data}

Pada tahap ini penulis mengumpulkan beberapa data termasuk mencari referensi yang mendukung karya inovasi pembelajaran penulis. Penulis menggali literature baik di perpustakaan maupun dengan informasi yang ada diinternet.

\section{Desain produk}

Sebagai langkah pertama penulis mendesain garis ajaib untuk menerangkan materi bilangan bilangan bulat.

Adapun bentuk desainnya seperti pada gambar di bawah ini; 
Tanti Ratna Wulandari
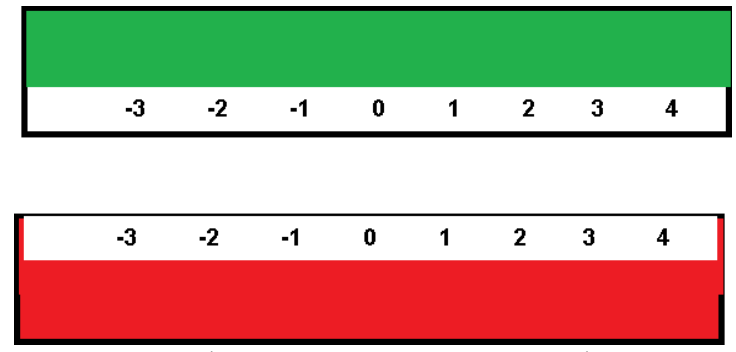

Gambar 6 Desain Garis Ajaib

\section{Validasi desain}

Dalam kesempatan ini penulis melakukan pengujian desain untuk diterjemahkan ke benda nyata. Dalam perkembangannya penulis menerima saran dari beberapa teman sejawat agar desain direvisi untuk memudahkan pekerjaan dan simulasi.

\section{Revisi desain}

Setelah penulis melakukan beberapa analisis dan menambah literasi di berbagai sumber termasuk internet dan buku pelajaran di perpustakaan akhirnya desain dirubah dengan membuat papan utama dan garis geser.

Adapun bentuk prototype dari garis ajaib ini adalah sebagai berikut :

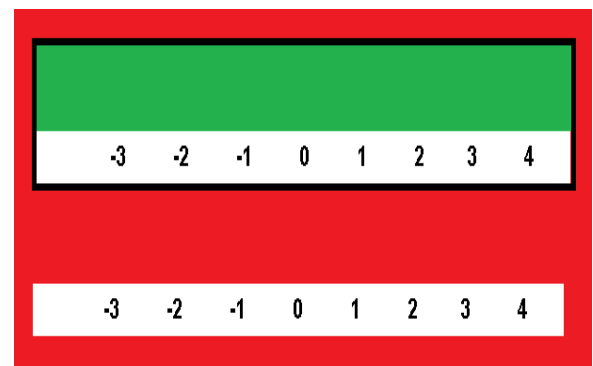

\section{Uji coba prototype}

\section{Gambar 7 Desain revisi Garis Ajaib}

Pengujian prototype dari Garis Ajaib dilakukan di kelompok kecil. Dalam kelompok kecil ini penulis melakukan observasi pada mereka tentang bagaimana menggunakan garis ajaib untuk membantu konsep 
pemahaman mereka tentang operasi bilangan bulat.Dari hasil ujicoba prototype didapati bahwa peserta didik cukup antusias namun mengalami kekurangpraktisan dalam pengoperasian garis ajaib. Sehingga penulis merasa memerlukan sedikit penyempurnaan.

\section{Revisi produk}

Seperti yang sudah dikatakan di atas, penulis melakukan sedikit penyempurnaan pada garis ajaib untuk memudahkan pengoperasiannya. Untuk mempermudah penggeseran garis geser maka penulis menambahkan materi pipa gorden Sehingga didapati desain akhir dari garis ajaib seperti pada gambar di bawah ini;

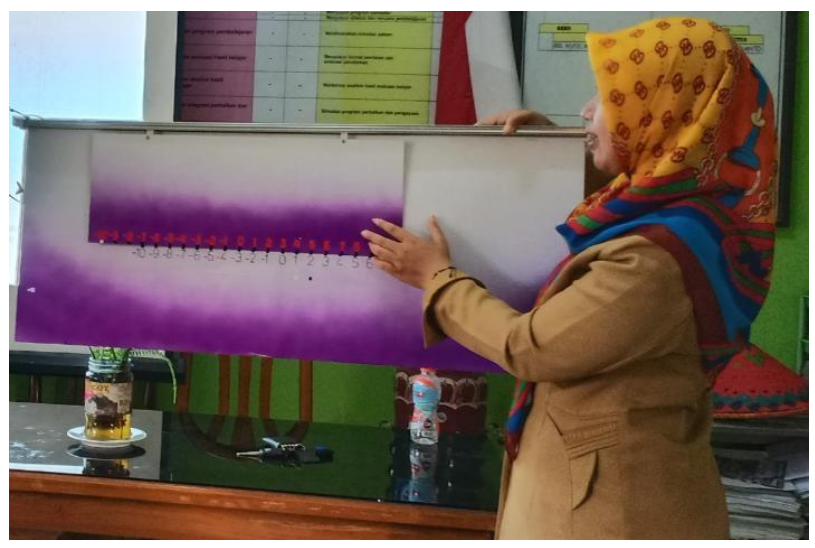

Gabar 8 Hasil Akhir Pembuatan Garis Ajaib

\section{Penerapan dalam pembelajaran}

Setelah finishing pembuatan produk maka langkah selanjutnya adalah melakukan perbaikan pembelajaran dengan menggunakan karya inovasi pembelajaran garis ajaib yang telah penulis buat dalam rangka meningkatkan pemahaman kelas VI SDN Wates Kecamatan Wates kabupaten Kediri pada materi bilangan bulat. 


\section{Diseminasi}

Setelah diadakan pembelajaran dan pengolahan data serta penulisan laporan langkah berikutnya adalah mendiseminasikan produk garis ajaib di lingkungan KKG Gugus 1 SDN Wates.

Aplikasi Praktis dalam Pembelajaran

Langkah-langkah pembelajaran menggunakan garis ajaib adalah sebagai berikut;

a. Siswa dibagi ke dalam beberapa kelompok

b. Siswa memperhatikan penjelasan guru tentang penggunaan garis ajaib

c. Siswa mengerjakan tugas yang diberikan dengan menggunakan garis ajaib pada kelompoknya

d. Siswa maju dalam kelompok untuk menerangkan operasi hitung bilangan bulat dengan garis ajaib

e. Siswa mengerjakan tugas individu

f. Guru memberikan penguatan

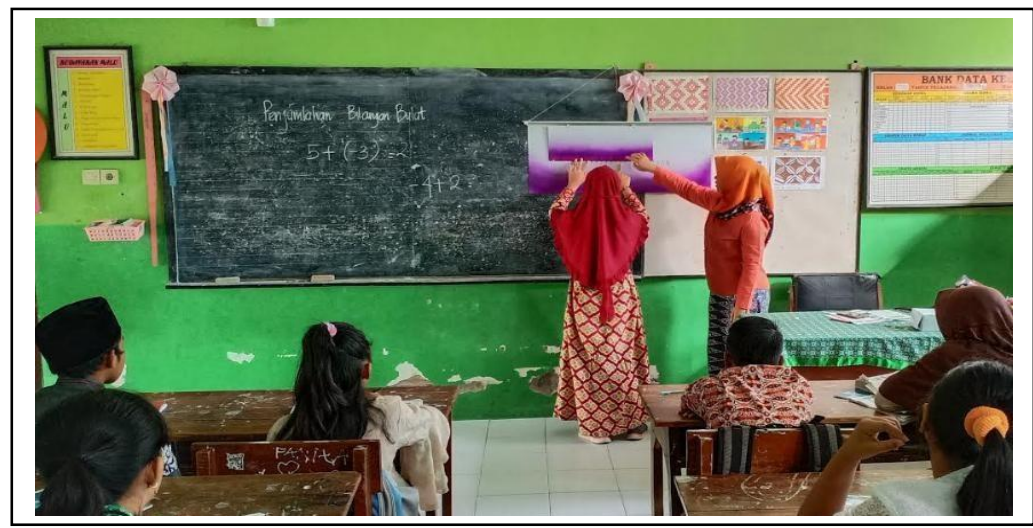

Gambar 9 Proses Pembelajaran dengan Garis Ajaib

\section{Analisis Hasil Aplikasi Praktis Pembelajaran}

Setelah proses pembelajaran, diadakanlah ulangan harian dengan data seperti nampak pada diagram di bawah ini 


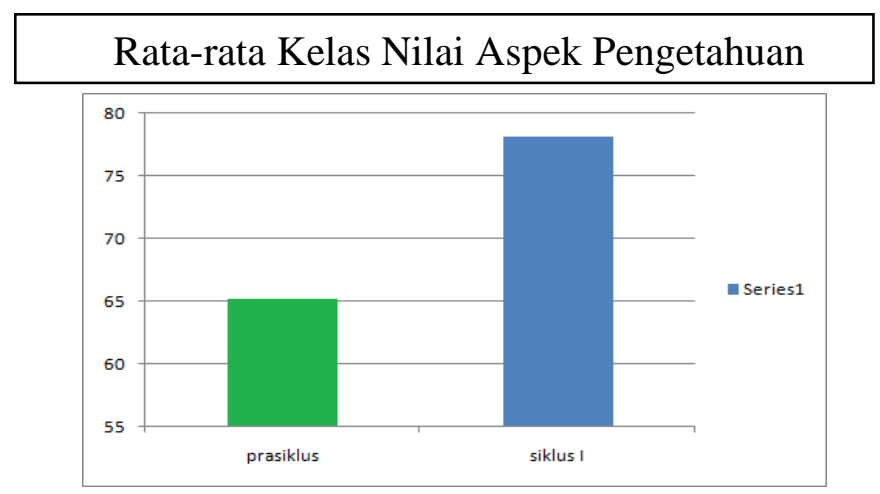

Gambar 10 Grafik perolehan rerata kelas aspek pengetahuan antarsiklus

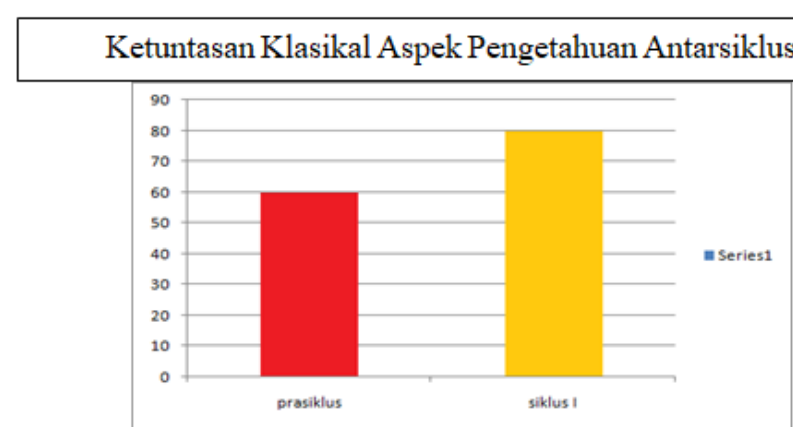

Gambar 11 diagram ketuntasan klasikal aspek pengetahuan antarsiklus

Rata-rata Kelas Nilai Aspek Pengetahuan Antarsiklus

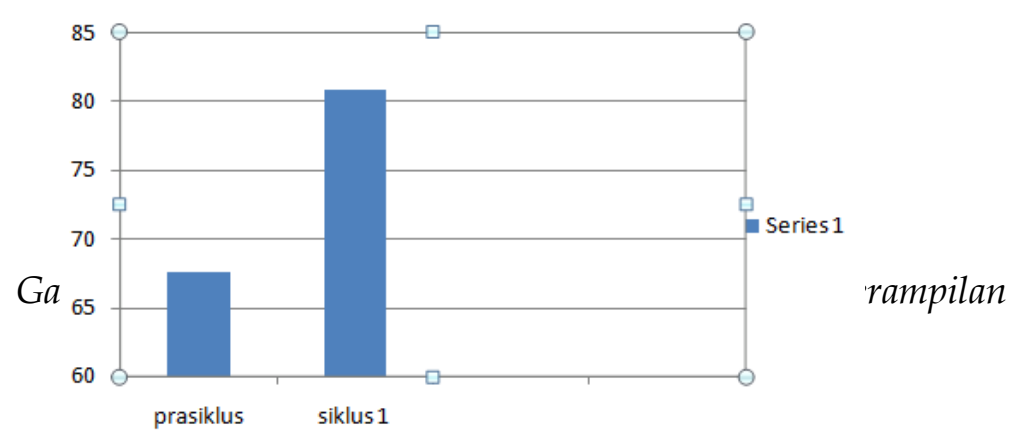

Sedangkan dari ketuntasan belajar dapat disajikan dalam grafik di bawah ini: 
Ketuntasan Klasikal Nilai Aspek Pengetahuan Antarsiklus

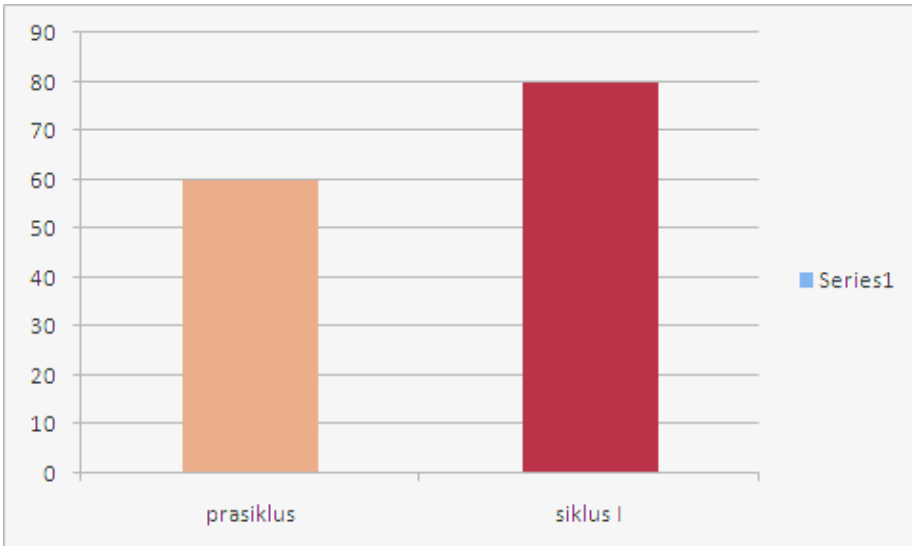

Gambar 3.13 grafik ketuntasan KKM pada aspek keterampilan antarsiklus

Dari grafik data di atas dapat dikatakan telah terjadi peningkatan hasil belajar yang ditandai dengan :

1) Terdapat peningkatan pencapaian KKM pada aspek pengetahuan. Yakni dari 60 di prasiklus naik menjadi 80 pada siklus I

2) Terdapat peningkatan pencapaian rata-rata kelas dari semula hanya 65,2 lalu naik menjadi 78,2 di siklus I

3) Terjadi peningkatan pencapaian KKM pada aspek keterampilan yakni yang semula hanya di angka 60 pada prasiklus lalu naik menjadi 80 pada siklusII

4) Terdapat peningkatan rata-rata nilai kelas pada aspek keterampilan, yakni pada siklus I hanya pada nilai 67,6 lalu naik menjadi 80,8 di siklus I.

\section{Evaluasi}

Setelah dilakukan perbaikan dan diujicobakan lagi, maka penulis merasa bahwa media pembelajaran Garis Ajaib ini cukup efektif dimanfaatkan oleh guru dalam pembelajaran Matematika pada materi Bilangan Bulat. Hasil evaluasi menunjukkan bahwa siswa merasa senang belajar memanfaatkan media tersebut. Guru juga merasa lebih mudah menjelaskan materinya bahwa hanya beberapa saat saja siswa sudah paham. Hal ii menunjukkan bahwa media ini cukup efektif dimanfaatkan 
oleh guru dan siswa dalam pembelajaran di kelas, bahkan siswa secara aktif belajar untuk hitungan-hitungan yang lain. Dengan demikian, media ini sebaiknya dapat dimanfaatkan oleh guru SD kelas VI lain di seluruh Indonesia. Semoga bermanfaat.

\section{Penutup}

\section{Simpulan}

Dari hasil penelitian ini, dapat disimpulkan sebagai berikut:

a. Media Garis Ajaib merupakan media untuk mengajarkan materi bilangan bulat negatif dengan sistem simulasi agar siswa bisa memahami konsep operasi penjumlahan dan pengurangan bilangan bulat dan Media Garis Ajaib sangat mudah direduplikasi karena terbuat dari bahan yang mudah didapat disekitar kita.

b. Proses pembelajaran dalam penerapan Media Garis Ajaib sangat interaktif dan menyenangkan karena siswa dapat terlibat langsung dalam pembelajaran untuk menemukan konsep materi bilangan bulat.

c. Prestasi belajar siswa Kelas VI SDN Wates Kecamatan Wates Kabupaten Kediri bisa meningkat dengan dikembangkanya media GarisAjaib.

d. Penulis berharap adanya masukan, kritik dan saran demi penyempurnaan laporan ini baik langsung maupun tidak langsung lewat email yang tertera pada lampiran.

e. Apabila ingin mengunakan media Garis ajaib hendaknya lebih dulu menganalisis kesesuain dengan materi serta sarana dan prasarana agar bisa maksimal hasilnya.

f. Sebagai guru, penulis mengajak para guru untuk lebih inovatif dan kreatif didalam pembelajaran.

\section{Saran}

a. Guru dalam pembelajaran sebaiknya memanfaatkan media pembelajaran agar siswa termotivasi dalam pembelajarannya. 
b. Guru sebaiknya mampu mengembangkan media sendiri sesuai dengan permasalahan siswa yang ramah lingkungan dan berbasis kearifan lokal.

c. Dalam pengembangan pembelajaran sebaiknya melibatkan siswa, guru lain, dan didiskusikan dengan.

d. Dalam pembelajaran Matematika dengan materi Bilangan Bulad sebaiknya guru memanfaatkan media garis ajaib yang ternyata efektif untuk mengajarkan materi tersebut.

e. Sebelum memanfaatkan media guru sebaiknya menganalisis kondisi siswa apakah memungkinkan pemanfaatan media tersebut.

f. Guru harus terus kreatif dan belajar agar dapat mengikuti perkembangan ilmu dan teknologi.

\section{Ucapan Terimakasih}

Artikel ini ditulis berdasarkan Naskah Perlombaan Karya Inovasi Pembelajaran Guru SD Tingkat Nasional tahun 2019 yang diselenggarakan oleh Kesharlindung, Direktorat Guru dan Tenaga Kependidikan, Kemendikbud. Karena itu, penulis sampaikan terima kasih kepada Direktorat GTK, kepada editor jurnal Didaktika Pendidikan Dasar dan kepada semua pihak yang telah membantu pelaksanaan penelitian.

\section{Daftar Referensi}

Komalasari, Kokom .(2015). Pembelajaran Kontekstual: Konsep dan Aplikasi. Bandung: PT. RefikaAdiatama.

Karso, Dkk. (2014). Pendidikan Matematika 1. Tangerang Selatan: Universitas Terbuka.

Isjoni. (2016). Cooperative Learning: efektifitas belajar kelompok. Bandung: Alfabeta.

Sugiyono.(2017). Metode Penelitian. Bandung: Alfabeta.

Susilana Rudi, Riyana Cepi. (2012). Media Pembelajaran. Bandung: Wacana Prima 
Suyono dan Hariyanto. (2017). Belajar dan Pembelajaran : Teori dan Konsep Dasar. Bandung: Remaja Rosda Karya.

Wilandari, Rahmi. (2019). Membangun karakter generasi milenial menghadapi era revolusi industri 4.0. Media, 5,62-64. 